Finnish history documentaries as history culture

\author{
Kortti, Jukka Petteri
}

2016-10-03

Kortti , J P 2016 , ' Finnish history documentaries as history culture ' , Studies in

Documentary Film , vol. 10 , no. 2 , pp. 130-144 . https://doi.org/10.1080/17503280.2016.1221673

http://hdl.handle.net/10138/227985

https://doi.org/10.1080/17503280.2016.1221673

cc_by_nc

acceptedVersion

Downloaded from Helda, University of Helsinki institutional repository.

This is an electronic reprint of the original article.

This reprint may differ from the original in pagination and typographic detail.

Please cite the original version. 


\title{
Finnish History Documentaries as History Culture
}

\author{
Jukka Kortti
}

Artide (Accepted version)

\section{Post-print (ie final draft post-refereeing)}

Original citation: Jukka Kortti (2016) Finnish history documentaries as history culture, Studies in Documentary Film, 10:2, 130-144, DOI: 10.1080/17503280.2016.1221673

\begin{abstract}
:
This article approaches Finnish documentary films as part of current history culture and 'sense of history'. Through three examples of Finnish documentary films, it examines the relationship between history documentaries and academic history with reference to the modes of documentary filmmaking and to history theories. In analysing the films, the 'orientation' of the films as well as their 'organization' is of interest. The article is particularly interested in national history representations and media memory. It emphasises the production context of the films. The article suggests that in order to understand history documentaries as a part of history culture means taking into consideration the particular history culture in question, the documentary tradition of a country, and, first of all, the production context of a documentary.
\end{abstract}

Keywords: history documentaries, history culture, sense of history, Finnish documentary

\section{Introduction}

There has been a 'history boom' - a consuming or commodification of history - in the 2000s. According to the Dutch historian Jerome de Groot $(2009$, 17), history has become a significant part 
of popular entertainment. This phenomenon concerns a wide range of cultural realms in which history is presented, such as biographies, novels, antiques, fiction films - and documentary films.

A recent study (Torsti 2012) on Finnish historical consciousness shows that Finns are 'history people.' They are interested in the past in many ways. Compared to three other countries (USA, Australia, and Canada), where the same kind of research project was conducted, Finns top the charts practically in every form of history activity amongst ordinary people when they were asked in the surveys about their history activities during the last twelve months. All in all, according to the survey, you could say that Finns are exceptionally keen on re-enacting history - the concept that has exercised historians' as well as documentary filmmakers' minds for some time. Other related concepts such as reconstructing, sensing history, collective and cultural memory as well as questions of 'truth' and 'authenticity' are common both in documentary film and history theories.

Since the 1990s, there has been a heyday of Finnish documentary film that has produced a wide range of different approaches to Finnish culture and society, and to its past. In this article, I approach Finnish documentary films as part of the history culture and sensing of history. The main interest of the article is to study how national history representations and media memory are realized in Finnish history documentaries. I am particularly interested in the relationship between history documentaries and academic history with reference to the modes of documentary filmmaking (Nichols 2001) and history theories. I studied the relationship between documentary film and history theory through a case study (Aaltonen \& Kortti 2015) earlier, but in this article I widen the spectrum both in terms of cases and theories. And in conclusion, I ponder what my example analyses says about Finnish history culture in general and what is needed to be taken into consideration when analysing history documentaries as part of history culture. 


\section{History culture and sensing history}

The concept of history culture refers to the wide range of activities in which images and information about the past are produced, mediated, and used, and also to the ways in which historical consciousness is socially constructed and expressed in different societies. These ways in which history culture is expressed include visiting museums, exhibitions, buildings and archives, educational system, tourism, personal histories and media. They help societies and individuals to construct concepts of themselves, their environment, and the world around them.

The concept emerged among West German historians in the 1980s due to the very complex and difficult German history of the $20^{\text {th }}$ century. One of the key theorists in the field, the German historian Jörn Rüsen (1994, 219-225), has divided history culture (Geschisctskultur) into three dimensions: cognitive (kognitive), aesthetic (ästhetische), and political (politische). In history documentaries, these dimensions are effectively always present.

Making historical sense (Historische Sinnbildung), on the other hand, as a concept includes a wide range of phenomena that make meaning out of the past. It is a result of a creative process of the human mind in which the past is given its importance in terms of the present and how people understand the past, how they think about it. In this process, memory obviously plays a crucial role (Rüsen 2008a). 
In defining 'sense of history' (Sinn der Geschichte), Rüsen (2008b, 53-56) divides the phenomenon into three dimensions: content, formal and function, which are all coherently interrelated. As the cognitive dimension of history culture, content refers to the 'quality of experience' and reason. It means that we are provided some factual or other information about the past and its development towards our time.

The formal dimension in sensing history means, first and foremost, historical narrative. A cogent historical narrative or other form of chronology is one of the dimensions of the aesthetic dimension of history culture as well, albeit only one aspect in it. However, the importance of the formal dimension in sensing history refers particularly to ritual forms of history culture. In a documentary, it could be obtained in several ways such as by re-enacting the past or through talking about or drawing upon memories.

Historical sense also has a functional dimension. In that case the orientation of the presentation becomes crucial. The relationship between the past and the present is then particularly relevant. As Rüsen $(2008 b, 55)$ puts it, “[s]tories and histories must provide answers to questions shared by narrator and addressee alike, if they, the stories and histories, are to have, and make, 'sense' within this communicative context." This often, though not always, means the political dimension of history culture when history is subordinated to serve a certain purpose.

\section{Films and methodology}

I have chosen three films (or programmes) for my qualitative analysis: Suomi on venäläinen part 4: Pietari (Yle, Intervisio 2015); Kansakunnan käännekohta, part 2: Opiskelijaradikalismi Suomessa 
saa väkivaltaisia muotoja vuoden 1968 mellakoissa (Yle, Moskito Television 2006), and Kuka piru pimeässä näkee (L.P.M.A Productions 2014). The sample is not by any means representative of all history documentaries made in Finland recently, but I have chosen the films that are particularly interesting from the point of view of the modes, if not trends, of documentary filmmaking as well as history culture. Suomi on venäläinen (Finland is Russian) was chosen particularly since the topic of the series, Russian and the history of Finno-Russian relations, has been so current recently due to Ukrainian conflict. Kansakunnan käännekohta ('The Turning Point of the Nation'1) was particularly interesting from the point of 'sensing history' since it is a mocumentary. In Kuka piru pimeässä näkee (Who the Devil Can See in the Dark) memory plays a crucial role and it represents personal documentary genre, which has been popular approach in Finnish documentary filmmaking in the 2000s. In relation to the production and distribution context, there is an emphasis on television in the article since two of them, Finland is Russian and 'The Turning Point of the Nation' are parts of a television series. Who the Devil Can See in the Dark was shown in cinemas (Helsinki International Film Festival, 2015) before its TV premiere.

According to the well-known modes of a documentary set out by film theoretician Bill Nichols (2001, 102-138), these films might be categorized as follows: Finland is Russian represents the expository mode. It is a 'traditional' television documentary that directly addresses the viewer with arguments and perspectives presented by the presenter and the talking heads in recounting history. Who the Devil Can See in the Dark could be classified as falling into the participatory mode, though it has elements of the performative mode as well. 'The Turning Point of the Nation' is a mocumentary hence in classifying the programme according to Nichols's modes depends on how we approach it. As a 'real documentary' it could be classified into both the expository and the participatory mode but as a 'fictional documentary' it could classify in the reflexive mode. 
However, since Nichols's classification is problematic to a certain degree (they involve ambiguities), they could also be classified according to the documentary prototypes set out by the media scholar Ib Bondebjerg $(2014,16)$. He classifies documentary films as authoritative, observational, dramatized, and poetic-reflexive. Hence in Bondebjerg's types, 'The Turning Point of the Nation' could be classified as a dramatized documentary, Finland is Russian as authoritative, and Who the Devil Can See in the Dark as poetic-reflexive.

In analysing the films, I am particularly interested in the metafunctions (see Halliday, 1973, 1978 and on adaption if it, Idema 2004) of the films, especially their orientation - how meanings position the characters and the readers-viewers. In practice, this refers to the way in which subjects in the documentaries are positioned through film technics (camera angles, shots, scenes, etc.). I am also interested in their organization - how the meanings of the films are sequenced and integrated into a story.

I strongly emphasize the context of a film. Given the view of film historian Barbara Klinger (1997), who has emphasized, in analysing films synchronically, the importance of production (cinematic practices), and the intertextual, social, and historical context of a film, ${ }^{2} \mathrm{I}$ want to concentrate in particular on the production context of the films to be analysed. Emphasising the production context of media has been characteristic of my research work. For instance, in my study (Kortti 2003) on the history of Finnish television advertising, besides the cultural products - the advertising films the institutions and people are brought into focus as well. The working conditions of television advertising, and particularly their changes, are given attention. 


\section{Discussing the nation}

The intertextual context, however, is crucial in the first documentary in question, Finland is Russian. In order to understand the whole idea of the documentary series fully, you need to know the background to the series since Finland is Russian is actually a continuation if not a spin-off of the series Suomi on ruotsalainen (Finland is Swedish) broadcast on YLE's channel TV1 in the spring of 2013 (YLE is Finland's national public service broadcasting company). It was produced by the same production company (Intervisio) that produced Finland is Swedish, with the same director (Tommi Pietiäinen) and the same presenter (Juhani Seppänen). Finland is Swedish was a series about the Swedish influence on the Finnish way of life and Finland is Russian was produced accordingly about Russian influences in Finland.

Finland is Swedish created a fuss in the Finnish public sphere, especially in social media, when it was broadcast. The series was accused, among other things, of being Swedish-speaking ${ }^{3}$ propaganda and there was 'hate speech' aimed at the presenter Juhani Seppänen, for instance. Hence, the controversy of its predecessor set a certain tone for the Finland is Russian documentary series. Finland is Russian, however, did not create a similar outburst of hatred or other black-andwhite debates as its predecessor, but the Russian military interventions in Ukraine during the broadcast gave the programme a very contemporary feel. Discussions about the topic of each episode continued online on the web site of the programme (see website "Suomi on venäläinen"). The idea of integrating social media into a television programme is rather common in current television broadcasting, but Yle in particular has emphasised it in its social media strategy (See website "Ylen toimintaperiaatteet"). 
Under the circumstances and in terms of the production context, it is important to highlight that the series is made for the Finnish national broadcasting company Yle. Although the series was made by an independent production company, it is shot through with a public service ethos. In its expository mode the tone of the series is educational. No matter how controversial (or perhaps just because of it) the topic of the programme was, it could easily be argued that it was true to the spirit to inform, educate, and entertain - the well-known Reithian ideal - as well as to contribute to national identity and a sense of community. Or as Yle's current mission statement ("This is Yle") states: "Yle strengthens Finnish society and culture by providing everyone with information, education, insights and experiences."

Finland is Russian could be seen as quite traditional 'television history' since it is presenter-led and it uses academics and other professionals as talking heads. However, there are some particularities that do not fit the traditional character of a history documentary as found in BBC history documentaries, for instance, such as Civilization (BBC2, 1969) or A History of Britain (BBC1, 2000-2002). Firstly, the presenter Juhani Seppänen, who is navigating us in the sea of complex Finnish-Russian relations for the whole ten episode series, is not a historian (e.g. Simon Schama), or a journalist (e.g. Jeremy Paxman), or an actor (e.g. Stephen Fry), but a company doctor and a writer. He became a public intellectual after writing a book about Finnish alcohol culture and hosting a television programme on the topic. Moreover, there is not a tradition of presenter-led history documentaries in Finland, since most documentaries are usually led by a voice over. ${ }^{4}$

Another thing that makes Finland is Russian exceptional as an expository document is that it lacks archive footage. But how does the programme position people and things in it and us as viewers? In other words, what is the orientation of the programme $?^{5}$ 
In the fourth episode of Finland is Russian the presenter, Seppänen, visits St. Petersburg. He is casually walking around the city and talking about the history of the city, which is pictured as a major metropolis, as it spreads out in front of us in all its glory. The grandeur of the city's architecture is highlighted through low-angle shots and the city looks sunny and relaxed. People in the streets, both in St. Petersburg and in Helsinki, are interviewed about similarities between the two cities and nobody has anything negative to say about the neighbouring city and its people, quite the contrary. Historians, ambassadors, and other experts are also interviewed in both cities.

During the interviews the camera stays still, but when Seppänen is in the shot there is continuous movement as he is walks out of the picture in almost every sequence. In general, the editing, the cinematography, and other cinematic techniques make the documentary look modern. The production value is relatively high for a Finnish telefilm and obviously the fact that the director Tommi Pietiläinen has a long career in advertising film and music video productions is etched in the documentary series in the form of a visual language.

The Helsinki shots are located in front of the Uspenski Orthodox Cathedral and other architectural similarities between Helsinki and St. Petersburg. In almost all the episodes, there are high-angle shots on to Helsinki's Senate Square with the statue of the Russian Emperor Alexander II located in the centre of the square, and the Market Square with its Obelisk monument to Empress Alexandra. However, Seppänen also refers to Finnish influences on the early twentieth-century architecture of St. Petersburg and states ironically that if Hollywood is in need of a city that looks like St. Petersburg, it should come to Helsinki - referring to the fact that Helsinki featured as St. Petersburg in several Hollywood films, such as Warren Beatty's epic Reds (1981), during the Cold War era. 
Formally Finland is Russian is rather conventional. The organization of the episode studied here consists of visiting St. Petersburg, comparing it to Helsinki, and pondering the importance of St. Petersburg to Finnish culture and society. Functionally if not politically the episode confirms the myth of Finns as a hard-working, reliable, and educated people who enjoyed a good reputation in St. Petersburg when Finland was an autonomous Duchy of the Russian empire. Another, almost mythical, topic discussed, in Finland is Russian is Finnish 'vodka tourism' in Leningrad during the Soviet era. The documentary also states that despite Russia's cultural influences, Finns never really adapted Russian habits and manners. The main importance of St. Petersburg in Finland was that it was the home of the Russian Emperor and that 'the Greatest Finn of all times', namely, Marshall C.G.E. Mannerheim lived there as a Russian officer before the Russian revolution and before Finland won its independence.

\section{Contrafactual turmoil}

At the end of the St. Petersburg episode of Finland is Russian, the programme asks how the city would have developed if the Russian Revolution had never happened. The Russian historian Aleksandr Rupasov only briefly offers the view that the modernisation of St. Petersburg would probably have been more effective and that the city would have developed into a mega polis. The programme then asked a 'what if' question.

In 2006, Yle TV2 broadcast a six episode series titled 'The Turning Point of the Nation'. It concerned several revolutionary instances in the history of Finland, but in a counterfactual sense. It speculated what would have happened if certain crucial events in Finnish history had not ended as 
they had. The series included the common conventions of a television documentary, such as a presenter, testimonials, interviews with acedemics, and news clips or other contemporary films. But, besides the archive films and pictures (but often in a fictional context) everything in the documentary was not only re-enacted but also false. Hence as a form of dramatizing history, it reminds one of a mocumentary. However, there is also a meta level in the series since the presenter, actor Carl-Kristian Rundman as himself, also talks about what actually happened. Hence 'The Turning Point of the Nation' could be characterised as a mixture of mocumentary and docudrama.

The second episode of the series was titled in English: 'Finnish Student Radicalism Breaks out in Violence in the 1968 Riots'. In reality, there were no actual violent student revolts in the 'year of the barricades' (Caute, 1988) in Finland although there were other kinds of activities among youth during the unrest of that year. The key event in Finnish student radicalism of the sixties was the occupation of the Old Student House in Helsinki in March 1968, but unlike other acts of international student activism (notably the occupation of the Sorbonne University in May '68 Paris or the second occupation of Columbia University in New York in that year), the Old Student House occupation was nonviolent if not entirely peaceful.

One Finnish peculiarity in the context of the international student activism of the 1960s was that the President of Finland (1956-1982), Urho Kekkonen - a former student radical of the 1920s supported the action. So when the students in France and the United States bayed for their presidents to resign, the President of Finland invited young radicals to wine and dine at his residence (the famous so-called ‘Children's Parties') (see Kortti 2014, 13-14). Kekkonen sympathised with left-wing radicalism although his background was in the non-socialist (Agrarian) Centre Party. The president's attitude was partly due to his practical domestic policy's tactics 
against the conservatives on the one hand and domesticating leftist forces on the other. And his indispensable position in the crucial relationship between Finland and the Soviet Union in the context of the Cold War gave him opportunities to use the so-called 'Moscow card' when his authority was threatened. This partly guaranteed his re-election in the 1968 presidential election. In the Electoral College, the conservative candidate of the major right-wing National Coalition Party, a bank manager Matti Virkkunen came second with just 66 votes against Kekkonen's 201 votes.

Nevertheless, in 'The Turning Point of the Nation' episode Kekkonen does not manage to get the Social Democrats or even his own Centre Party behind him and he decides not to run for a third term. Virkkunen is elected President, which starts riots. The University of Jyväskylä in Central Finland was occupied by the radicals in the spring 1968. The police used force in taming the occupation and it turns violent. But the main riot starts in Helsinki around the Old Student House on the First of May. ${ }^{6}$ When the police decide to use rubber bullets and tear gas the demonstrations became violent and there were many serious injuries. In the following occupation of the Swedish Theatre two radicals are killed in the police attack.

According the mocumentary, Finland was in a chaotic state and the Soviet Union sent Finland a diplomatic note because of the unrest in its neighbour to the West. The Soviets were afraid that youth in the Eastern Bloc, such as in Czechoslovakia, would copy the actions by the Finns. The Finnish Army was called to break up the barricades and there were more casualties. Finally, as a result the Government of Finland and later also President Virkkunen resigns. In the following year, Kekkonen is re-elected and the situation is normalized. So the idea of the programme was that the 1968 student revolt went in a direction other than the one that it actually took. 
However, the orientation of 'The Turning Point of the Nation' uses a rather conventional history documentary rhetoric of the expository mood. But according to the conventions of a mocumentary, all of the people interviewed in the episode are fictional, including the academics. The episode also contains $8 \mathrm{~mm}$ substandard home films about a fictional student leader. These acted and fictional elements, which were made specifically for the programme, were mixed in with the real images from archive footage to create a counterfactual view.

'Counterfactuality', or 'virtual history', became a sort of trend in history studies in the 1990s and the 2000s. An important milestone was the collapse of the Eastern bloc, although historians had speculated on different possible historical paths before that - especially in relation to the Second World War. Nevertheless, the conjectures have aggravated the political situation in the postcommunist part of Europe. Though being controversial and full of aspects of the politics of history, many - especially political or contemporary - historians regard counterfactuality as useful since it reveals topical issues (see, e.g., Ferguson 1997; Hobsbawm 1997, 150-151; Kalela 2012,89-93).

You could say that Finnish historians were at the forefront of interest in such topical issues since two Finnish What if... compilations were published (Niemi \& Pernaa 2005; Jokisipilä \& Niemi 2006a) by professional historians in the mid-2000s. The books attracted some discussion both for and against among critics and scholars and the books were mainly seen as an interesting contribution to history. As the editors stated in the second book, it suggests that it may even be useful for a historian occasionally to detach himself or herself from a historically accurate view of the world and to speculate with 'what if scenarios' in order to achieve a wider perspective on history (Jokisipilä \& Niemi 2006b, 10). Ultimately, different kinds of speculations and what-if 
scenarios have become more and more popular in television history programmes as well (see e.g. de Groot 2009, 115; Ebbrecht 2007).

This kind of reconstruction and re-enactment of history, as in 'The Turning Point of the Nation', obviously raises questions about 'truth', the cognitive element of history culture. Truth has been a tricky concept for historical theory since the 'linguistic turn' of the 1960s when it became a relativist concept in the sense that proposed that there are always different types of knowledge and people attach different meanings to truth. However, a professional historian must always try to remember that his or her job is to make sense of the past, not to act as judge or jury, not to provide society with a moral compass (Kalela 2012, 82, 105, 110-111.). The claim is tested particularly if he or she presents 'what if' scenarios.

From the point of view of documentary film, there is usually a social contract between an audience and a filmmaker. "We expect documentary to deal with real events, real people and actual problems of the world we live in", as Ib Bondebjerg $(2014,14)$ puts it. A filmmaker is expected to deliver a truthful and honest representation of events. ${ }^{7}$ Mocumentaries break this rule. Some of them question or challenge our concepts of truth and our ability to learn about things through the media, while some deal with strong social or otherwise difficult issues, which would be otherwise difficult to make, and others just take the form of a documentary film to entertain, such as mocumentary classics like Zelig (Woody Allen, 1983) and This is Spinal Tap (Bob Reiner, 1984)

However, as Bill Nichols (1991, 107, 111) emphasizes in his Representing Reality, documentaries are close to fictional narrative in organizing the plots, locations, characters, etc., although their 
representation differ from fiction film. He also notes that a documentary "addresses the world in which we live rather than the world in which we may imagine living" (Ibid, 112), but a mocumentary blurs this "fundamental difference" as well.

In terms of organization, the formal dimension of the 'The Turning Point of the Nation' is centred around the reminiscences of the fictional student leader's former girlfriend. She takes a trip down memory lane remembering her late boyfriend and looking back on those turbulent times in the same way that real documentaries do. It is obvious that memory plays a central role in history documentaries.

\section{On transgenerational memory}

It could be said that in Mari Soppela's film Who the Devil Can See in the Dark memory plays one of the main roles. The documentary is about Soppela herself searching, on behalf of and together with her father, for her grandfather, who was a German soldier. Soppela's grandmother left Finland during the war and returned with a child, her father. The synopsis of the film is as follows:

During World War 2, German soldiers left an invisible genetic legacy across Europe. They had affairs with local women in the allied and the occupied countries. Tens of thousands of children were born during the war. Most of the war children, now in their 70s, have only recently started to search for their fathers. Filmmaker Mari Soppela's father is no different.

Who the Devil Can See in the Dark is about a father and a daughter, finding and meeting their lost \& found family. How has this father's fatherlessness shaped them and their relationship?

Using a Scandinavian style of shooting - static camera \& long held takes - the film manages to blend real and cyber landscapes. The journey begins in Finland and goes on to Amsterdam, Norway, and Germany, before coming together in Finnish Lapland. Here we have the consequences of war for three generations and two families. Will there be closure? (The website of the documentary) 
Again, it is crucial to know the context of the film, particularly Soppela's background as a filmmaker. She had already made two other documentaries about her family, and it is particularly important to have some knowledge of the first one called Family Flies (2001) because Who the Devil Can See in the Dark is a follow-up to that film. That acclaimed, award-winning film was about Soppela's family roots in Finnish Lapland. In that film, she reconstructed a history of her family across four generations using letters, photographs, home movies, and interviews. There are some tragic patterns in the family tree, which are linked to her grandmother Helvi's life. A couple of Soppela's relatives made a complaint saying that Soppela had invaded their privacy and the film was then banned and has not been shown since. Finally, due to a court decision in 2008, Soppela had to cut certain parts of the film. This background is revealed in the beginning of Who the Devil Can See in the Dark.

The film starts with an intimate shot of Soppela and her father Kari Soppela lying on a sofa, watching old photographs and discussing Kari's mother. Kari tells how he was ashamed of her as a kid. However, he do not admit that he would has suffered some form of trauma because of his mother. It soon appears that it is Soppela herself who has a transgenerational traumatic relationship with her grandmother. As the Finnish film critic and historian Antti Alanen (2015) noted, "[t]he film feels like the director's therapy exercise into which we are invited. But there is nothing pathological here. Instead, there is a droll sense of humour." This funny side of the film is realised not only in Kari's unwillingness to participate in his daughter's obsession, but also when they ponder together which of the German soldiers stationed in Lapland really "knocked her up." 
In Soppela's case, you could talk about postmemory (Hirsch 2001) or secondary memory, which means collective memories transmitted, often through media, to a second generation of people who have not experienced the actual events but have adapted the traumatic tensions of the first generation. In the beginning of Who the Devil Can See in the Dark, there are some statistics about the number of children fathered by German soldiers in Europe during the war. And right after the opening shot of the two characters sitting on the sofa, which could be seen as a formative point of the whole film, collective memory starts to mix with individual memory.

The media has a significant role in mediating collective and cultural memory. As the key theoretician in the field, French sociologist Maurice Halbwachs (1992) put it in his On Collective Memory in the 1920s, historical representations have an important role in creating collective memory. In fact, media and memory have become interwoven to such an extent that we can speak of mediated memories, as the Dutch media scholar José van Dijck $(2007,15-21)$ has noted. But he also emphasizes that mediated memory is not an internal, physiological human capacity in and of itself. Rather, the media is an external tool that manipulates this human capability to build and shape memories. Hence the media and memory transform each other and contemporary media has created a new memory.

Referring to Halbwachs's seminal work, Israeli media scholars (Neiger et.al 2011, 1) talk about media memory, outlining it as "the systematic exploration of collective pasts that are narrated by the media, through the use of the media, and about the media." Their idea stems from the notion that collective memory is essentially mediated nowadays. Who the Devil Can See in the Dark is most obviously about the first part of the definition - how memory is narrated in the media. But the film also works as a tool for working and processing memory. 
This phenomenon obviously concerns our sensing of history. In a compilation that examines how television has shaped collective memory in the media age, Gary R. Edgerton (2001, 5) describes the media as representing 'the full sweep of historical consciousness, understanding, and expression that a culture has to offer ${ }^{6}$. As one of the early theoreticians of mediation (or mediatization ${ }^{8}$ ), media sociologist John B. Thompson $(1995,24)$ has stated, the development of communication media has created mediated historicity. The flow of historical images, such as certain famous archival film clips, creates a collective consciousness (see also Anderson 2001, 19-22; Hoskins 2001, 334-335).

Who the Devil Can See in the Dark works more on a subjective than a collective level - or rather it could be said that subjective private memory is in tension with collective memory. This separation is often blurred in today's media saturated world. Therefore, as media scholar Jérôme Bourdon $(2011,66)$ emphasizes, media texts need to be analysed at the level of micro-social practices. This means that it is important to see how collective memory is incorporated at the individual level. After all, the sense of history has traditionally meant a "subject quality of the temporal change of the human world." (Rüsen 2008b, 41) Whilst the sensing of history has been seen more and more as subjective thinking, the thematization of remembering and memory has increased the inner quality of historical experience.

Besides the intimate discussions between father and daughter and with individuals who might be their German relatives, another characteristic of Who the Devil Can See in the Dark is the use of computer snap shots and Google's Earth application in mapping the locations ('cyber landscapes' mentioned in the synopsis) in Finland, Norway, Holland, and Germany. Moreover, old photographs are showed in stop-go motions as is the case using a computer mouse. These means are obviously 
influenced by Soppela's main profession as the programmer and interaction designer. Nevertheless, all this outlines the aesthetic rhetoric of the search. Formally, however, the film is rather conventional in an Aristotelian sense: there is a problem, an attempt to solve it, and a solution.

\section{Conclusion}

Of the films dealt with in this article, Who the Devil Can See in the Dark best represents recent trends in Finnish documentaries. Besides 'using a Scandinavian style of shooting' ${ }^{9}$, the subjectivity and reflexivity of the document reminds one of the personal or subjective documentary genre, which was the mainstream of Finnish documentary filmmaking in the 2000s. Although Soppela has lived outside Finland almost all her professional life, she started her studies in video filmmaking in Oulu in the 1990s. Therefore, she has obviously absorbed the ideas of creative documentary independent and ambitious (off television) documentary productions - of the 1990s Finnish documentary genre (see Aaltonen 2006, 72-80.)

The increase in the use of a personal approach in Finnish documentary filmmaking has meant that the 'personal reminiscence' method (Rosenthal 2002, 300) has characterized Finish history documentaries. But as Jouko Aaltonen, one of the few scholars (Aaltonen is also a documentary film maker) who has studied Finnish history documentaries wrote in his published doctoral thesis (Aaltonen 2006, 60-71) a decade ago, other types of history documentary films have been made in Finland. According to Alan Rosenthal's (2002, 300-306) classification, these include historical essays on the subject of choice and 'great man' documentaries, where history is viewed through the eyes of a renowned person. 
To re-emphasise, the history documentaries chosen for this analysis are by no means a representative sample of all Finnish history documentaries made in 2000s. For instance, to mention the most apparent, there are no films by such auteur film makers as Seppo Rustanius and Peter von Bagh. Rustanius has concentrated especially on the traumatic years of the Finnish Civil War and other turmoils of the era. In terms of academic history, his films are interesting because he is usually very precise and strict about the historical accuracy and authenticity of his films (Aaltonen 2006, 77). Internationally renowned film historian, critic, festival director and filmmaker von Bagh (1943-2014), on the other hand, has produced a wide range of documentaries about the history of Finland, which all have a very recognisable (essayist, poetic, montage, compilation) mode.

But as often with these kinds of taxonomies, different types are mixed in practice. However, the classification of history documentary films helps to characterize the different ways of approaching the past. The classifications are also dependent on the production and distribution context (for TV or film theatre or perhaps only online), the generation of the filmmaker as well as trends in documentary filmmaking.

My decision to choose two television documentary history series was no accident. The role of television as one of the most important agents for communicating historical events has been important since the first years of television. Before major global media events such as landing on the moon in 1969, the most remarkable television events for Finns were sports, especially track and field (the first Finland-Sweden Athletics International was televised in 1958, and the first televised Olympics were 1960 Summer Olympics in Rome), and the annual beauty pageant of Finland competitions Miss Finland since 1959. Television is a mediator and a creator of collective (or media) memory and a significant factor in the history of culture (or public history) in general. 
Television is a visual media and a good storyteller and educator, which may encourage people to learn more about history (On television and history, see e.g. Roberts \& Taylor 2001; Edgerton \& Rollins 2001; Cannadine 2004; Gray 2013; Aaltonen \& Kortti 2014).

Torsti's $(2012,40-44)$ study referred to in the introduction showed that approximately all of the Finns in the survey (96 per cent compared to approximately 80 per cent in other countries) had watched history programmes and movies on TV. Of their history interests as a whole, watching history related television programmes or movies were the most common activity among Finns. The study also shows - perhaps not so surprisingly - that history on TV is watched most often by men aged between 40 and 49 and that the older generations are more interested in history than the younger generations.

In this sense, Finland is Russian and 'The Turning Point of the Nation' documentaries are good representatives of 'television history' under the programme policy of the national broadcasting company since there is an apparent effort in both series to attract younger audiences. The age groups under 25 have been very problematic audience segments in the age of mobile phones, Netflix and other Internet television service: how to avoid losing them as an audience? In the more recent film Finland is Russian this is realized in the modern editorial rhythm and frequent use of low and high angle shots. In 'The Turning Point of the Nation' the use of $8 \mathrm{~mm}$ material is not only a tool to create romantic nostalgia, but also to make a reference to the music video aesthetics of the 1990s and 2000s. 
From the point of view of history culture and making sense of history, their orientation is interesting in a cognitive sense, in that their approaches to contemporary history are highly managed in terms of the present. And instead of providing - not even pretending to provide - fully factual information about the past in terms of history politics, 'The Turning Point of the Nation' makes its audience to think about the past in a different way. And this is not realized only in the form of a 'what if scenario' but also in a pedagogical sense as the when a viewer is orientated to see the development of Finnish history in a more international context. This could be seen as one of the major goals of Finland is Russian as well.

This orientation to find new angles to national history can be seen as characteristic of Finnish history culture in recent years. For instance, the role and position of Finland in the Second World War as well as approaching the war from the point of view of women, everyday life, or other previously marginalised points of view have increased in the 2000s. The relationship with Russia/Soviet Union is one of the major controversial issues in the recent history of Finland, and a discussion about Finland's attitude during the Cold War started right after the collapse of the Soviet Union.

Nevertheless, history is the narrative construction of the human mind and cultural orientation in human life. To create a sense of the experiences of the past, history uses cognitive means, whereas to bring this sense into the effective cultural framework of the human mind it uses poetical and rhetorical means (Rüsen 2005, 4-5). In this process, I think, history documentary film is a major contributor. 
In documentary films, there has been a clear tendency to move from evidence-based, constructed history presentations towards the re-enactment of history. It is obvious that along with the development of the image-reading skills of people, an audience does not rely on visual evidence that much anymore. Instead of looking for evidence, audiences are looking for a socially constructed experience of history (see also Aaltonen \& Kortti 2015).

According to Rüsen (2008b, 50), "[s]ense is situated beyond the distinction between factuality and functionality; it is an earlier synthesis of both." He sees, first and foremost, that sense "synthetizes 'ego time' and 'world time"' in forming the identity of an individual. In shifts in the theory of history (particularly the emergence of postmodernism since the 1970s), historical sense has lost its rationality and objectivity has disappeared as a meaningful concept in historical thought.

Therefore, when people know that everything can be falsified, a filmmaker does not necessarily need to lay claim to authenticity and truth. However, 'The Turning Point of the Nation' shows that it is possible to produce compelling virtual history without computer-generated imagery (CGI), which is often problematic in the production of Finnish documentaries on relatively small budgets. But we must remember, however, that documentary film makers have always been using various ways of using the rhetoric of cognition and emotion (Bondebjerg 2014, 14); imagination, different narrative elements and audio-visual means, etc., are not children of the digital age.

The history documentary genre is a significant contributor in today's history culture. But in order fully to understand the weight of history documentaries in history culture, we need to analyse their 
nuances. This means taking into consideration the particular history culture in question, the documentary tradition of a country, and, first of all, the production context of a documentary.

\section{References}

Aaltonen, Jouko, and Jukka Kortti. 2015. "From Evidence to Re-Enactment: History, Television and Documentary Film” Journal of Media Practice, 16 (2): 108-125.

Alanen, Antti. 2015. "Film Diary. Who the Devil Can See in the Dark / Kuka piru pimeässä näkee". Thursday, March 05, 2015. http://anttialanenfilmdiary.blogspot.fi/2015/03/who-devil-can-see-indark-kuka-piru.html.

Ampuja, Marko, Juha Koivisto, and Esa Väliverronen. 2014. "Strong and Weak Forms of Mediatization Theory: A Critical Review.” Nordicom Review 35. Special Issue: 111-123.

Anderson, Steve. 2001. "History TV and Popular Memory.” In Television Histories. Shaping

Collective Memory in the Media Age, edited by Gary R. Edgerton, and Peter C. Rollins. Kentucky: The University Press of Kentucky.

Bondebjerg, Ib. 2014. "Documentary and Cognitive Theory: Narrative, Emotion and Memory." Media and Communication, 2 (1): 13-22.

Bourdon, Jérôme. 2011. "Media Remembering: the Contributions of Life-Story Methodology to Memory/Media Research.” In On Media Memory. Collective Memory in a New Media Age, edited by Motti Neiger, Oren Meyers, and Eyal Zandberg, 62-73. Houndmills, Basingstoke, Hampshire, New York: Palgrave Macmillan. 
Cannadine, David, ed. 2004, History and the Media. New York: Palgrave MacMillan.

Caute, David. 1988. Sixty-Eight: the year of the barricades. London: Hamish Hamilton.

Dijck, José van. 2007. Mediated Memories in the Digital Age. Stanford: Stanford University Press. de Groot, Jerome. 2009. Consuming History. Historian and heritage in contemporary popular culture. London and New York: Routledge.

Ebbrecht, Tobias. 2007. "Docudramatizing history on TV German and British docudrama and historical event television in the memorial year 2005." European Journal of Cultural Studies 10: $35-53$.

Edgerton, Gary R. 2001. "Introduction" in Television Histories. Shaping Collective Memory in the Media Age, edited by Gary R. Edgerton and Peter C. Rollins, 1-16. Kentucky: The University Press of Kentucky.

Ferguson, Niall, ed. 1997, Virtual History. Alternatives and Counterfactuals. London: Picador.

Gray, Ann. 2013. "History Documentaries for Television." In The Documentary Film Book, edited by Brian Winston, 328-335. London: BFI, Palgrave Macmillan.

Halbwachs, Maurice. 1992. On Collective Memory. Chicago: The University of Chicago Press. Halliday, Michael Alexander Kirkwood. 1973. Explorations in the Functions of Language. London: Edward Arnold.

Halliday, Michael Alexander Kirkwood. 1978. Language as Social Semiotic. London: Edward Arnold.

Hirsch, Marianne. 2011. "Surviving Images: Holocaust Photographs and the Work of Postmemory." The Yale Journal of Criticism 14 (1): 5-37. 
Hobsbawm, Eric. 1997. On History. London: Abacus.

Hoskins, Andrew. 2001. "New Memory: Mediating History." Historical Journal of Film, Radio and Television 21 (4): 333-346.

Iedema, Rick. 2004. “Analysing Film and Television: a Social Semiotic Account of Hospital: an Unhealthy Business". In The Handbook of Visual Analysis, edited by Theo Van Leeuwen, and Carey Jewitt, 183-207. London: Sage.

Jokisipilä, Markku, and Mari K. Niemi, eds. 2006a. Entä jos...Lisää vaihtoehtoista Suomen historiaa. Helsinki: Ajatus Kirjat.

Jokisipilä, Markku, and Mari K. Niemi. 2006b. ”Vahingollista, viihdyttävää vai jopa välttämätöntä? Miksi myös tapahtumaton kuuluu historiaan.” In Entä jos...Lisää vaihtoehtoista Suomen historiaa, edited by Markku Jokisipilä, and Mari K. Niemi, 7-17. Helsinki: Ajatus Kirjat.

Kalela, Jorma. 2012. Making History. The Historian and Uses of the Past. Hampshire: Palgrave McMillan.

Klinger, Barbara. 1997. "Film History Terminable and Interminable: Recovering the Past in Reception Studies.” Screen 38 (2): 107-128.

Kortti, Jukka. 2003. Modernisaatiomurroksen kaupalliset merkit. 60-luvun suomalainen televisiomainonta. Helsinki: SKS.

Kortti, Jukka. 2014. "Media, the Elite and Modernity. Defining the Modern among Finnish Cultural Intelligentsia in the 20th Century." Internationanl Journal for History, Culture and Modernity 2: (1): $1-24$.

Lundby, Knut. 2009. Mediatization. Concept, Changes, Consequences. New York: Peter Lang.

Nichols, Bill. 2001. Introduction to Documentary. Bloomington: Indiana University Press. 
Nichols, Boll. 1991. Representing Reality: Issues and Concepts in Documentary. Bloomington: Indiana University Press.

Niemi, Mari K., and Ville Pernaa, eds. 2005. Entä jos... Vaihtoehtoinen Suomen historia. Helsinki: Ajatus Kirjat.

Neiger, Motti, Oren Meyers, and Eyal Zandberg. 2011. “On Media Memory: Editor’s Introduction.” In On Media Memory. Collective Memory in a New Media Age, edited by Motti Neiger, Oren Meyers, and Eyal Zandberg, 1-24. Houndmills, Basingstoke, Hampshire, New York: Palgrave Macmillan.

Rüsen, Jörn. 1994. Historische Orientierung: über die Arbeit des Geschichtsbewusstseins, sich in der Zeit zurechtzufinden. Köln: Böhlau Verlag.

Rüsen, Jörn. 2005. History. Narration-Interpretation-Orientation. New York, Oxford: Berghahn Books.

Rüsen, Jörn. 2008a. “What does 'Making sense of history' mean?” In Meaning and Representation in History, edited by Jörn Rüsen, 1-5. New York, Oxford: Berghahn Books.

Rüsen, Jörn. 2008b. "Sense of History: What does it Mean? With an Outlook onto Reason and Senselessness." In Meaning and Representation in History, edited by Jörn Rüsen, 40-64. New York, Oxford: Berghahn Books.

Roberts, Graham, and Philip M Taylor, eds. 2001. The Historian, Television and Television History. Luton: University of Luton Press.

Rosenthal, Allan. 2002. Writing, Directing \& Producing Documentary Films. Carbondale and Edwardsville: Southern Illinois University Press.

“Suomi on venäläinen.” http://yle.fi/aihe/suomi-venalainen 
“This is Yle." https://drive.google.com/file/d/0B

v6fV6ewetZZ1pVSm9CUzRyYUU/view?pref=2\&pli=1

Thompson, John B. 1995: The Media and Modernity: A Social Theory of the Media. Stanford:

Stanford University Press.

Torsti, Pilvi. 2012. Suomalaiset ja historia. Helsinki: Gaudeamus.

Who the Devil Can See in the Dark official website (http://whothedevilcansee.com/)

"Ylen toimintaperiaatteet." http://yle.fi/yleisradio/toimintaperiaatteet/sosiaalisen-mediantoimintalinjaukset

1 'The Turning Point of the Nation' is my translation unlike the other films that have an official English title.

${ }^{2}$ Cinematic practices include film production, distribution, exhibition, and film personnel. Intertextual zones include relations to other businesses and industry, other media and arts, review journalism, and star journalism and fan culture. Social and historical contexts include the economy, law, religion, politics, class, race and ethnicity, gender and sexual difference, family, ideology, and cross-cultural reception.

${ }^{3}$ Finland was part of Sweden until 1809 when it became an autonomous Grand Duchy of the Russian Empire after the Napoleonic wars. Swedish was first and foremost the language of the upper class until the late $19^{\text {th }}$ century in Finland. The promulgation of the Parliament Act in 1906, when one of the world's most modern and democratic parliamentary systems was created, caused a drastic decrease of the Swedish-speaking elite's power in Finland. Finland got its independence in 1917. Since the Second World War, the Swedish-speakers have had a rather steady position in the Finnish cultural sphere and they have continued to be a distinct subgroup of the Finnish people yet their share of the total population has dropped from its nineteenth-century level (circa 7. 5 per cent in the early 1960s; 5.5 per cent in the 2000s). They have their own schools, universities, garrisons, television and radio channels, etc. According to the constitution, they have the right to communicate with the state authorities in their mother tongue. Half of all Swedish speakers live in areas in which Swedish is the majority language and they can use Swedish in all or most contexts. 
Finnish speakers also have to learn Swedish in school. Since most of the Finns do not need to speak Swedish at all and Russian would be a more useful language, especially in Eastern Finland, there have been discussions regarding the position of Swedish as a 'compulsory' language as well as the issue of having their own garrison recently. This discussion has partly come about because of the victory of the populist party, the True Finns, in the Finnish parliamentary election of 2011.

${ }^{4}$ The only person, who could be compared to such famous British charismatic presenters and enlightened lecturers such as Kenneth Clark (eg. Civilization. BBC 1969) or Schama is Yle's broadcaster, journalist, and correspondent in Paris and London Erkki Toivanen (eg. Henkinen Eurooppamme [Our European intellectual heritage], Yle 2010). ${ }^{5}$ I used the Finland is Russian episode for an assignment in my course on qualitative methods. Since my views are partly fuelled by the analyses provided by the students on that course, I want to thank all the students in the Qualitative Method Workshop, Social Science History, at the University of Helsinki in 2015.

${ }^{6}$ May Day in Finland is historically not only International Workers' Day but also students' day and a public holiday with a carnival atmosphere.

${ }^{7}$ For more about 'truth' regarding history theories and documentary films, see Aaltonen \& Kortti 2015.

${ }^{8}$ For a discussion on the concept of mediatization, see, for example, Ampuja et.al. 2014; Lundy 2009.

9 'Scandinavian style of shooting' refers to the generous use of static camera and long held takes. In Nordic fiction films, the most obvious examples are the films by Finnish Aki Kaurismäki and Swedish Roy Andersson. 